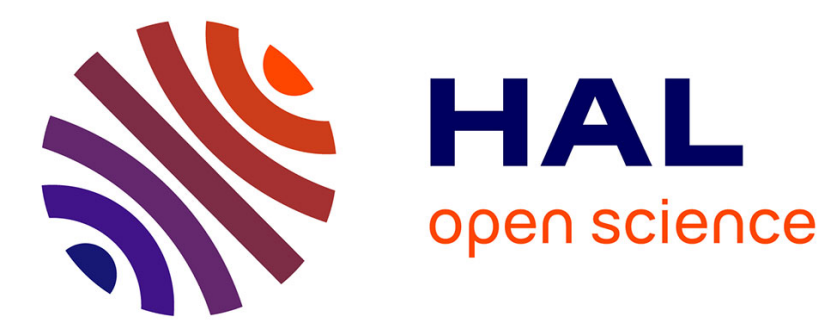

\title{
Humus forms in terrestrial ecosystems: a framework to biodiversity
}

Jean-François Ponge

\section{To cite this version:}

Jean-François Ponge. Humus forms in terrestrial ecosystems: a framework to biodiversity. Soil Biology and Biochemistry, 2003, 35 (7), pp.935-945. 10.1016/s0038-0717(03)00149-4 . hal-00498465

\section{HAL Id: hal-00498465 \\ https://hal.science/hal-00498465}

Submitted on 7 Jul 2010

HAL is a multi-disciplinary open access archive for the deposit and dissemination of scientific research documents, whether they are published or not. The documents may come from teaching and research institutions in France or abroad, or from public or private research centers.
L'archive ouverte pluridisciplinaire HAL, est destinée au dépôt et à la diffusion de documents scientifiques de niveau recherche, publiés ou non, émanant des établissements d'enseignement et de recherche français ou étrangers, des laboratoires publics ou privés. 
Type of contribution: Review paper

Date of preparation of the revised version: 24 December 2002

Number of text pages: 21

Number of tables: 1

Number of figures: 3

Humus forms in terrestrial ecosystems: a framework to biodiversity

Jean-François Ponge

Museum National d'Histoire Naturelle, CNRS-UMR 8571, 4 avenue du Petit-Château, 91800 Brunoy, France, tel. +33 1 60479213, fax +33160465009, e-mail: jean-francois.ponge@wanadoo.fr 


\section{Abstract}

Humus forms are the seat of most biological transformations taking place in terrestrial ecosystems, being at the interface between plants, animals and microbes. The diversity of terrestrial humus forms (mor, moder and mull) can be attributed to the existence of different patterns (strategies) for the capture and use of resources by ecosystems, in ascending order of biodiversity and bioavailability. Arguments are found in the parallel development of humus forms and terrestrial ecosystems, in exclusion mechanisms between organisms living in different humus forms, and in palaeontological studies. The diversification of terrestrial life forms in the course of Earth history, concomitant with an improvement in resource availability due to the development of sedimentary layers at the surface of continents, may explain the successive appearance of more active humus forms working the co-existence of an increasing number of organisms. Contradictory reports about the relationships between biodiversity and stability of ecosystems can be explained by the existence of different belowground pathways making ecosystems more stable.

Keywords: Humus forms; Biodiversity; Soil organisms; Communities; Biogenic structures; Feed-back processes

\section{Introduction}

Humus forms can be defined as morphological patterns observed in the association of organic matter with mineral matter at the top of soil profiles. To the light of recent developments in soil science and ecosystem dynamics (Bardgett et al., 1998; Ponge et al., 1998; Schwartz et al., 2000; Hooper et al., 2000; Lavelle, 2000; Landeweert et al., 2001; Klironomos and Hart, 2001) it can be suggested that humus forms play a central role in the functional biodiversity of terrestrial ecosystems. They are the stable, visible result of most animal and microbial life in the soil and, in a feed-back process, they condition the development of terrestrial plant, animal and microbial communities (Perry et al., 1989; Wardle et al., 1997; Ponge, 1999; Ponsard et al., 2000). We may wonder whether the observed variation in terrestrial humus forms just indicates the diversity of parent rocks and climates or, better, if it has something to tell us about biodiversity. The present paper is a revisitation of the original work of Müller (1889), who described humus forms on the basis of ecosystem properties and provided avenues for an ecological development of soil science. After a description of the three main humus forms, mull, moder and mor, mostly focussed on ecosystem processes and biodiversity levels, arguments will be presented proposing humus forms as hubs for the self-conservation of terrestrial ecosystems. Past history of the Earth will be examined to illustrate the increasing diversification of humus forms and their parental reltionships. The present paper offers arguments in favour of an evolutionary classification of humus forms and discusses their possible use as tools for the assessment of biodiversity. It will be focused on temperate, mountain and boreal ecosystems, given the experience of the author. 


\section{Mull: the fast use of nutrients}

Mull can be characterized by the rapid disappearance of leaf litter under the influence of burrowing animals (Staaf 1987) and/or white rots (Hintikka, 1970), and by the homogenization of humified organic matter with mineral particles within macro-aggregates (Bernier, 1998). The hemorganic $A$ horizon is the place where most soil organisms are living, plant roots included (Bornebusch, 1930). Fungi are present, both as saprophytic and mycorrhizal (VAM zygomycetes) species, but bacteria abound, due to the numerous mineral particles at the surface of which they adhere (Marshall, 1975) and primer effects from animal mucus (Barois et al., 1993) and root exudates (Cheng and Coleman, 1990).

Mull fauna exhibit a high biomass and a high species richness (Petersen and Luxton, 1982), including megafauna (moles, small rodents), macrofauna (earthworms, large arthropods, molluscs), mesofauna (mites, springtails, enchytraeids) and microfauna (nematodes, protozoa). Large animals typical of mull have more nutrient requirements (per unit of mass produced) than smaller-sized animals (Teuben and Verhoef, 1992).

Mull is associated with the most fertile soils (Brady and Weil, 1999) and supports an abundant and diversified herb layer which plays a significant role in the maintenance of a rich soil community (Wolters, 1999; Hooper et al., 2000). It is typical of grassland and deciduous forest ecosystems under mild climate (Green et al., 1993). In woodlands, the understory is characterized by a luxuriant, nutrient-rich vegetation (Bary-Lenger et al., 1992), with a low nutrient use efficiency (Vitousek 1982). Availability of nutrients is thus a prerequisite for the build-up of mull, but in turn mull is favourable to soil fertility through high nutrient input and turnover of nutrients (Schaefer, 1990). Mull is characterized by a rapid cycling of nutrients effected by a variety of organisms (plant roots included) living together in the topsoil (Vedder et al., 1996). Table 1 summarizes the main features of mull humus forms at the ecosystem level.

Buffering effects of earthworm mucus (Schrader, 1994; Barois et al., 1993) and easily weathered minerals (Ulrich, 1987) have been demonstrated. The availability of nutrients and the productivity of the ecosystem remain high even over a wide range of soil acidity providing that no disruption of the nutrient cycle occurs through uncontrolled man activities (Kimmins, 1977; Ponge et al., 1997).

\section{Moder: the conservation of nutrients through fungal and animal activity}

In moder humus forms macrofauna are smaller and reduced in abundance and diversity compared to mull (Schaefer, 1991), thus organic matter accumulates in the form of three holorganic horizons $\mathrm{OL}$ (entire leaves or needles), $\mathrm{OF}$ (fragmented litter) and $\mathrm{OH}$ (humified litter). The cementation of organic matter by mineral particles is nil or poor, due to the scarcity of adhesive 
substances such as mucoproteins or bacterial and root polysaccharides (Bernier and Ponge, 1994). Most microbial biomass is fungal, due to more acid conditions than in mull (Nagel-de-Boois and Jansen, 1967). Fungi produce antibiotics (Marx, 1969) which contribute to the collapse of bacterial populations, and they further acidify the soil by excreting organic acids (Takao, 1965).

Nutrients in moder are sequestered in decaying plant debris, faeces of epigeic fauna and fungi, which form the bulk of the OF horizon where most organisms are living (Webb, 1977; Cromack et al., 1977; Wolters, 1988). The colonization of OF horizons by fine tree roots and their associated mycelia (mostly ectomycorrhizal basisiomycetes) allows the vegetation to take up nutrients at the place where they have been released by detrital fungi and animals (Ponge, 1990). Due to the conservation of organic matter in the form of accumulated animal faeces and fungal biomass, nitrogen is abundant but mainly present as recalcitrant protein- $\mathrm{N}$ (dead fungal walls, animal cuticles, tanninprotein complexes).

The acidity of moder is high (low pH), due to the conjunction of cation preferences by plants (Nilsson et al., 1982), excretion of organic acids by fungi (Devêvre et al., 1996) and humification of organic matter (Stevenson, 1994). The chemical environment of moder-living organisms is characterized, not only by low $\mathrm{pH}$, but also by a concentration of heavy metals (Laskowski and Berg, 1993) and a high phenolic and terpenic content (White 1994; Gallet and Lebreton, 1995). The soil atmosphere, too, is characterized by pockets of high carbon dioxide and methane content (Verdier, 1975; Sexstone and Mains, 1990), due to the absence of carbonate buffering and poor redox values (Lafond, 1950; Lee, 1999). Since some important functions, such as burying of organic matter and creation of a network of large pores, are ensured only by macrofaunal groups (earthworms, millipedes, bibionid larvae), a decrease in functional biodiversity stems from the decrease in zoological richness observed between mull and moder (Table 1, Fig. 1, see also Schaefer and Schauermann, 1990).

Moder humus forms are mainly found in deciduous (oak, beech) and coniferous forests (Table 1), with depauperate ground flora and nutrient-poor litter (Howard and Howard, 1990). This process of impoverishment of the ground flora is further reinforced by the production of allelopathic substances (Jarvis, 1964).

\section{Mor: the immobilization of nutrients in plant organs}

Mor, often confused with dysmoder (moder with a thick $\mathrm{OH}$ horizon) under the vague designation of raw humus (Ulrich, 1987), is characterized by the scarcity of animal and white-rot activity. Undecomposed plant debris accumulate, forming a matted OM horizon with relatively few animal faeces (Barratt, 1964; Ponge et al., 2000). The matted OM horizon shows a sharp transition with the underlying mineral horizon impoverished in microaggregates (E horizon), contrary to moder where the transition with the mineral horizon is gradual (Nielsen et al., 1987). The poor nutritional value of mor restricts the production of the vegetation it supports and litter input is low (Aerts, 1995). 
Fire is the main agent of litter disappearance (Gimingham et al., 1979). Typically the vegetation is made of lichens, mosses and ericaceous shrubs (Bonan and Shugart, 1989), but cases occur where mor is present under coniferous trees such as pine and spruce, more especially under harsh environmental conditions (Northup et al., 1998) or when they have been introduced as exotic species (Nihlgård, 1971).

In this environment with a very poor biological activity, the most frequent associations of plants with fungi are the ascomycetous endomycorrhizae of ericales (Read and Kerley, 1995) and the association of coniferous trees (and less often deciduous trees) with the ascomycete Cenococcum geophilum, which is also present in dysmoder humus (Ponge, 1990). All these ascomycetous species are known for their efficiency in the use of organic nitrogen (Read and Kerley, 1995), which makes them able to transfer nutrients to the plants despite poor mineralization rates (Van Vuuren et al., 1992).

Mor originates from harsh (mostly cold) climate conditions or very poor parent rocks, and strong allelopathic properties of the associated vegetation (Gallet et al., 1999). The production of acidic substances by mor vegetation and the recalcitrant nature of the litter (Northup et al., 1995) contribute to further impoverish the soil by a positive feed-back process (Ulrich, 1987).

In mor humus forms vegetation takes a prominent place to the detriment of animals and microbes, which are at their lowest level of abundance and diversity (Davis, 1981). Dead and senescent parts of plants are the only seat of nutrient recapture, without resorting to humification/mineralization by saprophagous organisms (Aerts, 1995). Compared to mull and moder, the conservation of organic matter in mor is at its optimum and the release of nutrients at its minimum (Aerts, 1995). Although it has been claimed that the fitness of mor vegetation to environmental conditions it creates is good (Northup et al., 1998), it appears more realistic to think that severe disturbance events such as fires and avalanches and/or cyclic successions are involved in the longterm sustainability of present-day mor ecosystems (Heilman, 1966; Miles, 1985, Kaagman and Fanta, 1993).

\section{Humus forms as ecosystem strategies: three arguments}

The term strategy is used here to designate patterns involving plants, animals, microbes, and their common habitat, the humus form. It does not stem from a theoretical work. Rather, I will present several arguments which all aim at shaping a realistic, process-based view of the self-organization of ecosystems, which evolved and diversified in the course of Earth history. It can be hypothesized that a limited number of humus forms have evolved together with the development of terrestrial life as a response to scarcity or availability of nutrients and other environmental influences. The argumentation presented below lies on the observation of changes in humus forms, the knowledge of mechanisms by which humus forms are transformed or not, and ends by evolutionary aspects. 


\subsection{Argument 1: Changes in humus forms occur during the development of terrestrial ecosystems}

A succession of humus forms at the scale of a few decades has been demonstrated by chronosequence analyses in temperate, mountain and boreal late-successional forests (Page, 1974; Bernier and Ponge, 1994; Ponge and Delhaye, 1995). Mull is generally associated with early developmental stages (regeneration) of forest stands, moder with phases of intense growth of trees before they reach maturity, and mull recovers during maturity and senescence of the trees. This is consistent with the preparation of the regeneration niche in the mature forest, a step which is necessary for the renewal of late-sucessional ecosystems (Ponge et al., 1998). During the phase of intense growth of trees [aggradation phase sensu Oldeman (1990)], more nutrients are used for the build-up of wood than are released through litter decomposition and mineral weathering (Ulrich, 1987). During maturity of the forest stand the internal recycling of nutrients and the slower growth of trees yield more nutrients to the decomposer system (Nilsson et al., 1982). Earthworms are particularly sensitive to environmental changes occurring during tree stand development (Fig. 2), especially in coniferous stands but also in deciduous stands (Ponge and Delhaye, 1995). There is a global trend of decreasing abundance of earthworms during the phase of intense growth of trees (except a short spell following thinning operations), followed by progressive recovering as trees reach maturity then senesce (Bernier and Ponge, 1994). This process, which is probably controlled by tree physiology, can be considered as the driving force for the observed changes in humus forms. In old-growth forests, composed of a patchwork of small-sized eco-units (Oldeman, 1990), functional diversity may recover during maturity through colonization by herbs and mull-forming organisms which locally disappear during the phase of intense nutrient uptake by trees (Bernier and Ponge, 1994). Studies on chronosequences within late-successional forest ecosystems always concluded to a reversal under older trees in the process of soil acidification and organic matter accumulation (Page, 1968; Vitousek and Reiners, 1975; Bernier and Ponge, 1994).

\subsection{Argument 2: Exclusions exist between mull, moder and mor organisms}

Among soil animal groups, annelids always form a major part of soil animal biomass (Huhta and Koskenniemi, 1975; Standen, 1984; Schaefer 1991), but a clear distinction must be made between enchytraeids and earthworms. By compiling field data on mull and moder from several European authors who used reliable methods for extracting and counting both groups in grassland and woodland sites, it appears a clear discrimination between soils populated with earthworms and soils populated with enchytraeids (Fig. 3). The second-order hyperbolic equation fitted to the data indicates that soils with medium to high densities of both lumbricids and enchytraeids never occur in Europe. The strong departure from linearity of the curve (non-additivity of environmental responses) suggests that the relationship between earthworm and enchytraeid population sizes cannot be explained entirely by differential responses to environmental factors. A spatial exclusion between these two groups has been experimentally demonstrated by introducing earthworms in compost heaps 
colonized by enchytraeids (Haukka, 1987) but further experimental support is awaited before antagonism between enchytraeids and earthworms can be considered to play an active role in the differentiation between mull and moder.

Other interferences, such as those between fungi and bacteria (Dickinson et al., 1981), and between plants (Wardle et al., 1998) may as well be considered as mechanisms by which the development of humus form follows preferentially the mull, moder or mor pathway. Positive feedback loops (synergistic processes) involving plants, animals and microbes (Beare et al., 1995) could then be considered as amplifiers by which the whole ecosystem is transformed following some local or regional disturbance (Wardle et al., 1997). Among several examples, the long-term transformation of moder into mull still visible twenty years after the application of fertilizers should be highlighted (Deleporte and Tillier, 1999). On the contrary negative feedback loops (buffering systems) contribute to stabilize the ecosystems around equilibrium positions (Ulrich, 1987) which we expect to correspond to the three humus forms mull, moder and mor. The buffering effect of functional redundancy, i.e. the replacement of organisms ensuring the same function (Wolters, 1998), has been already suggested to explain the absence of visible change in humus form under present-day atmospheric pollution (Belotti and Babel, 1993). Personal observations that changes in humus form occur abruptly along linear environmental gradients point on the same combination of exclusion and stabilization processes (Gillet and Ponge, 2002).

\subsection{Argument 3: Humus forms evolved together with the diversification of life in terrestrial habitats}

Fossil records of soil biological activity are scarce, more especially concerning palaeozoic times when most of the evolution of terrestrial invertebrates took place (Retallack, 1985). Nevertheless Rhynian fossils (early Devonian, -400 million years) show a variegated fauna with most actual arthropod groups already present (Kevan et al., 1975). More information can be gained from the knowledge of past vegetation, if we consider present day representatives of the different plant phyla and their known relationships with humus forms. Given that the three main humus forms, namely mull, moder and mor, can be classified in a decreasing order of biodiversity, we can see them as steps in the evolution of terrestrial ecosystems.

Mor humus forms, with depauperate fauna and microflora, are associated with ericales, mosses, lichens, bryophytes, pteridophytes and, often, gymnosperms. If we discard ericales as recently evolved spermaphytes (Meyen, 1987), the rest of mor vegetation is typically made of plants evolved during palaeozoic times, mostly living at that time on Gondwana and Old Red Sandstone continents (Meyen, 1987). We may suspect that mor was the dominant humus form before the appearance of the first spermaphytes during the Carboniferous age ( -360 to -300 million years B.P.), and thereafter moder, at least in primitive forests. This is consistent with the present knowledge about the evolution of arthropods, with most radiation occurring during the Devonian age, i.e. from -410 to 360 million years B.P. (Dunger, 1987). Fossil records of tunnelling in vascular plants by oribatid mites 
(a typical moder process) are known from the Carboniferous age only (Labandeira et al., 1997). Given what we know of present environments colonized by lichen, moss, fern and gymnosperm vegetation, we can see palaeozoic terrestrial habitats as an acid world. Data about the composition of the Earth's atmosphere corroborates this idea, acid rains reinforcing the acidifying effects of primitive vegetation (Budyko et al., 1987).

Mull humus forms appeared probably after the explosion of flowering plants during the Cretaceous age ( -135 to -65 million years B.P.), i.e. when litter reached a better nutrient quality and was thus able to sustain abundant and diverse macroinvertebrate populations. This coincided with the massive emergence of limestone following coalescence of continental plates during mesozoic times (Budyko et al., 1987). Eathworm burrows were unknown from the primary era, the oldest records being dated from the beginning of the secondary era (Retallack, 1986). Given the absence of fossils it is hard to trace the evolution of earthworms, but the geographic segregation between the European Lumbricidae (now still invading North America from the first European settlements) and more evolved Circumpacific and Pantropical families such as Megascolecidae and allies (Dindal, 1990) is in favour of the late addition of earthworms to already highly diversified terrestrial invertebrate fauna. These animals played probably a decisive role in the appearance of mull (Hayes, 1983), thus it may be argued that mull (with mesozoic molluscs, annelids and crustaceans) was probably much more recent than moder (with palaeozoic arthropods) and moder much more recent than mor (without fauna).

Variations in species composition of soil invertebrates have been noted in different humus forms (Wauthy, 1982; Arpin, 1991; Chagnon et al., 2000). The threshold of pH 5 was found as a limit between acidophilic and acido-intolerant springtail communities (Ponge, 1993), i.e. the same threshold as for vegetation (Roem and Berendse, 2000). The examination of morphological characters and the knowledge of phyletic relationships between species and genera of Collembola revealed that, within each lineage, species and genera considered as near from the ancestor were acidophilic (Ponge, 2000). While still limited to a single invertebrate group, this examination of phyletic data is an additional argument for considering moder and mor as primitive humus forms compared to mull.

The view that ecosystems evolved towards a greater diversification of life forms, with an increasing complexity of functional relationships and a higher productivity, in the order mor-modermull, is in agreement with the application of thermodynamic laws to the successional development of ecosystems (Odum, 1969). Rusek (1978), studying soil animal communities along a successional gradient, observed an increase in the diversity of both plant and animal communities, earthworms and other macro-invertebrates being present only in late-successional stages. Price (1988) expressed the view that evolution selected the development of food webs of increasing complexity. Nevertheless it must be added that primitive assemblages were not totally replaced by more evolved ones, relicts of palaeozoic times such as mor and moder humus forms being now restricted to nutrient-poor sites where mull organisms cannot live. 


\section{Biodiversity and ecosystem processes: humus forms may help to clarify the debate}

Following intense theoretical speculations (Hutchinson, 1959; Odum, 1969; Menge and Sutherland, 1987), the effects of biodiversity on ecosystem processes have been tested experimentally (Vedder et al., 1996; Tilman, 1996; Tilman et al., 1997) and by comparing species-rich and species-poor communities (Wardle et al., 1997). Contradiction between expected and observed results (Coates and Rayner, 1985; Grime et al., 1987; Wardle et al., 1997) prompted Grime (1997, 1998) to recall that biological properties of organisms (as opposed to theoretical speculations) were fundamental to the knowledge of the interrelationships between ecosystem properties and biodiversity. The recognition of key organisms (Wolters, 1998), also called dominants (Grime, 1987) or ecosystem engineers (Lavelle et al., 1997), may help to better understand the fate of ecosystems under the influence of man or other disturbances (Sprugel, 1991), and in the course of successions (McCook, 1994). Key organisms shape their immediate environment in such a way that other organisms (called subordinates) can live only in the conditions thus created (Lavelle, 2000; Hooper et al., 2000). This concept is based on a hierarchical (holistic) consideration of causes and effects (Beare et al., 1995) which contradict what we know of the feed-back between organisms and their environment (Clarholm, 1985; Scheu et al., 1999; Ponge et al., 1999). The mutualistic concept (Wall and Moore, 1999) and the processing chain concept (Heard, 1994) are steps toward a more realistic approach, since they take into account interactions which give an advantage to one or both partners according to circumstances. Now let us examine how the concept of humus forms as ecosystem strategies can better explain the links between biodiversity and the stability and productivity of ecosystems.

The high plant, animal and microbial biodiversity and productivity observed in mull ecosystems can be explained first by more resources available to organisms (milder climate, higher richness of the parent rock), and second by the permanent disturbance created by the activity of organisms themselves. The coexistence of a number of different organisms creates more heterogeneity, thus it creates in turn conditions for the maintenance of a high variety of organisms (Hansen, 2000; Hooper et al., 2000). This occurs not only through mutualistic associations or facilitation processes, but also through switches in the occupation of space or in the use of nutrients when more species are living together (Anderson, 1978; Capowiez, 2000). More heterogeneity in the distribution of resources has been also demonstrated to increase plant productivity (Hutchings and Wijesinghe, 1997). Such a high level of biodiversity and productivity can be achieved only through a rapid cycling of nutrients which allows (and forces) organisms to adapt themselves to a constantly changing environment and to a high level of competition. Mull organisms have a low nutrient use efficiency, which means that they use more carbon per unit nutrient taken-up (Vitousek, 1982), because they have high energy costs for capturing space and nutrients at a high level of competition (Grime and Hodgson, 1987). This is both cause and effect of the high nutrient requirements of mull organisms (Piearce 1972). The stability of mull ecosystems when faced to pollution, climate change or soil impoverishment, i.e. their capacity to resist or recover after disturbance (Grime, 1987), is exemplified by the high level of acid input and heavy metal deposition needed before observing a shift from mull to moder or mor humus forms 
(Belotti and Babel, 1993; Gillet and Ponge, 2002). In the case of mull, its stability lies on a high level of functional redundancy, which is the positive side of competition (Belotti and Babel, 1993; Tilman and Downing, 1994). Such a system, by its high biodiversity, generates the conditions of its own stability, according to the bootstrapping effect described by Perry et al. (1989). Nevertheless it should be stressed that initial conditions for its build-up are a wealth of nutrients and a mild climate, as shown by Figure 1, and that severe limits appear when an important function such as burying of organic matter is ensured by only one and the same organism, for instance the earthworm Lumbricus terrestris (Bernier, 1996).

At the opposite, dearth of nutrient resources and harsh climate conditions prevailing in mor ecosystems impose a stricter use of energy and nutrients. Fewer species are present and functions fulfilled by the most exacting organisms (for instance burying of organic matter) are absent. Mor plants exhibit an intense production of recalcitrant and sometimes toxic secondary metabolites (Northup et al., 1998), which further decreases biodiversity (Wardle et al., 1997, 1998). The low productivity of mor ecosystems and the absence of internal disturbance (due to the poor number of competitors) allows a better nutrient use efficiency than in the case of mull (Aerts, 1995; Northup et al., 1998). The stability of such ecosystems is not ensured by the fast adaptation of a variety of organisms to constantly changing conditions, but rather to the durability of environmental conditions created by a few morforming organisms, more especially through the accumulation of recalcitrant organic matter (Meyer, 1964; Read, 1991; Näsholm et al., 1998) which isolates the ecosystem from outer harsh and poor environmental conditions.

Between these two extreme cases, moder ecosystems (or moder phases of the development of ecosystems) share advantages and disadvantages of both mull and mor strategies, by restricting the number of functional processes (compared to mull) while authorizing a still high level of biological activity. It is harder to understand how moder ecosystems are stabilized, and more knowledge about negative feed-back loops prevailing in moder is needed before approaching the reasons why this intermediary humus form is so frequent in deciduous and coniferous ecosystems, at least within the temperate zone. The existence of cyclic processes in moder ecosystems, with mull prevailing during the regeneration phase (Bernier, 1996), might suggest a solution to this enigma. Moder being associated with forest ecosytems (deciduous as well as coniferous), the existence of moder could well be explained by tree physiology. Since trees immobilize nutrients in their woody parts, the resulting impoverishment of the soil (Nilsson et al., 1982) necessitates an adaptation of the ecosystem, by restricting the number of competing organisms and improving nutrient use efficiency at the ecosystem level, at least during the phase of intense growth of trees, also called the autotrophic phase (Ponge et al., 1998). The need for woody parts to be decayed rapidly for the renewal of the ecosystem necessitates the preservation of enough biological activity and diversity during the heterotrophic phase (Ponge et al., 1998), also called the disintegration phase (Ulrich, 1987). Thus the stability of the ecosystem lies on alternating phases of high (mull) and moderately low (moder) levels of biodiversity. 
The recognition of three distinct (although not exclusive) strategies may thus help to understand why authors claimed that more species give more stability and productivity to ecosystems (which refers to the mull strategy) while others claimed the contrary (which refers to moder and mor strategies). It must be pointed out that no general model of stability and productivity can be constructed (Hooper et al., 2000), rather, a limited number of particular cases have to be identified, each of them having its own coherence within a regional set of ecological and historical factors (Wardle et al., 1997; Ponge et al., 1997). That each terrestrial ecosystem falls into one of the three above mentioned strategies is still a matter of conjecture, but this could be considered as the most realistic hypothesis explaining the limited number of observed solutions to the complex interplay between organisms and ecological factors. Although unachieved by lack of more experimental studies on interactions between soil organisms, the concept of humus forms as ecosytem strategies may help us to better understand the short-term and long-term effects of ecological crises such as land use changes, invading species, pollution, hurricanes or fires. All sudden environmental changes are amenable to the local extinction of species and, thus, above some given threshold of tolerance, of functions (Barros et al., 2001). Local changes in humus forms and important soil functional processes have been repeatedly described under the influence of pesticide and fertilizer use (Barratt, 1967; Topoliantz et al., 2000), heavy metal deposition (Coughtrey et al., 1979; Gillet and Ponge, 2002), plantation (Nihlgård, 1971; Muys and Lust, 1993), fire (Majer, 1984; Zackrisson et al., 1996) and liming (Deleporte and Tillier, 1999), among others. Some of these changes are irreversible, i.e. they persist a long time after original causes have disappeared (Koerner et al., 1997). To the light of present knowledge, we postulate that humus forms (shaped and stabilized by interactions between plants, microbes, animals and their physical environment) could well be the driving force which explains most of the observed variation in terrestrial ecosystems.

\section{REFERENCES}

Aerts, R., 1995. The advantages of being evergreen. Trends in Ecology \& Evolution 10, 402-407.

Anderson, J.M., 1978. Competition between two unrelated species of soil Cryptostigmata (Acari) in experimental microcosms. Journal of Animal Ecology 47, 787-803.

Arpin, P., 1991. Mise au point sur la caractérisation biologique des humus forestiers par l'étude des Nématodes Mononchida. Revue d'Écologie et de Biologie du Sol 28, 133-144.

Bardgett, R.D., Wardle, D.A., Yeates, G.W., 1998. Linking above-ground and below-ground interactions: how plant responses to foliar herbivory influence soil organisms. Soil Biology and Biochemistry 30, 1867-1878.

Barois, I., Villemin, G. Lavelle, P., Toutain, F., 1993. Transformation of the soil structure through Pontoscolex corethrurus (Oligochaeta) intestinal tract. Geoderma 56, 57-66.

Barratt, B.C., 1964. A classification of humus forms and micro-fabrics of temperate grasslands. Journal of Soil Science 15, 342-356.

Barratt, B.C., 1967. Differences in humus forms and their microfabrics induced by long-term topdressings in hayfields. Geoderma 1, 209-227. 
Barros, E., Curmi, P., Hallaire, V., Chauvel, A., Lavelle, P., 2001. The role of macrofauna in the transformation and reversibility of soil structure of an oxisol in the process of forest to pasture conversion. Geoderma 100, 193-213.

Bary-Lenger, A., Évrard, R., Gathy, P., 1992. La Forêt. Écologie, Gestion, Économie, Conservation. Éditions du Perron, Liège.

Beare, M.H., Coleman, D.C., Crossley, Jr., D.A., Hendrix, P.F., Odum, E.P., 1995. A hierarchical approach to evaluating the significance of soil biodiversity to biogeochemical cycling. Plant \& Soil 170, 5-22.

Belotti, E., Babel, U., 1993. Variability in space and time and redundancy as stabilizing principles of forest humus profiles. European Journal of Soil Biology 29, 17-27.

Bernier, N., 1996. Altitudinal changes in humus form dynamics in a spruce forest at the montane level. Plant \& Soil 178, 1-28.

Bernier, N., 1998. Earthworm feeding activity and development of the humus profile. Biology \& Fertility of Soils 26, 215-223.

Bernier, N., Ponge, J.F., 1994. Humus form dynamics during the sylvogenetic cycle in a mountain spruce forest. Soil Biology \& Biochemistry 26: 183-220.

Bonan, G.B., Shugart, H.H., 1989. Environmental factors and ecological processes in boreal forests. Annual Review of Ecology and Systematics 20, 1-28.

Bornebusch, C.H., 1930. The fauna of forest soil. Det Forstlige Forsøgsvaesen 11, 1-158.

Brady, N.C., Weil, R.R., 1999. The Nature and Properties of Soils, $12^{\text {th }}$ ed. Prentice Hall, Upper Saddle River.

Budyko, M.I., Ronov, A.B., Yanshin, A.L., 1987. History of the Earth's Atmosphere. Springer, Berlin.

Capowiez, Y., 2000. Differences in burrowing behaviour and spatial interaction between the two earthworm species Aporrectodea nocturna and Allolobophora chlorotica. Biology \& Fertility of Soils 30, 341-346.

Chagnon, M., Hébert, C., Paré, D., 2000. Community structures of Collembola in sugar maple forests: relations to humus type and seasonal trends. Pedobiologia 44, 148-174.

Cheng, W., Coleman, D.C., 1990. Effect of living roots on soil organic matter decomposition. Soil Biology \& Biochemistry 22, 781-787.

Clarholm, M., 1985. Possible roles for roots, bacteria, protozoa and fungi in supplying nitrogen to plants. In: Fitter, A.H., Atkinson, D., Read, D.J., Usher, M.B. (Eds.), Ecological Interactions in Soil. Plants, Microbes and Animals. Blackwell, Oxford, pp. 355-365.

Coates, D., Rayner, A.D.M., 1985. Fungal population and community development in cut beech logs. III. Spatial dynamics, interactions and strategies. The New Phytologist 101, 183-198.

Coughtrey, P.J., Jones, C.H., Martin, M.H., Shales, S.W., 1979. Litter accumulation in woodlands contaminated by $\mathrm{Pb}, \mathrm{Zn}, \mathrm{Cd}$ and $\mathrm{Cu}$. Oecologia 39, 51-60.

Cromack, Jr., K., Sollins, P., Todd, R.L., Crossley, Jr., D.A., Fender, W.M., Fogel, R., Todd, A.W., 1977. Soil microorganism-arthropod interactions: fungi as major calcium and sodium sources. In: Mattson, W.J. (Ed.), The Role of Arthropods in Forest Ecosystems. Springer, New York, pp. $78-84$ 
Davis, R.C., 1981. Structure and function of two antarctic terrestrial moss communities. Ecological Monographs 51, 125-143.

Deleporte, S., Tillier, P., 1999. Long-term effects of mineral amendments on soil fauna and humus in an acid beech forest floor. Forest Ecology and Management 118, 245-252.

Devêvre, O., Garbaye, J., Botton, B., 1996. Release of complexing organic acids by rhizosphere fungi as a factor in Norway spruce yellowing in acidic soils. Mycological Research 100, 1367-1374.

Dickinson, C.H., Dawson, D., Goodfellow, M., 1981. Interactions between bacteria, streptomycetes and fungi from Picea sitchensis litter. Soil Biology \& Biochemistry 13, 65-71.

Dindal, D.L., 1990. Soil Biology Guide. Wiley, New York.

Dunger, W., 1987. Some remarks on the role of the soil in the evolution of early Antennata. In: Striganova, B.R. (Ed.), Soil Fauna and Soil Fertility. Nauka, Moscow, pp. 198-202.

Gallet, C., Lebreton, P., 1995. Evolution of phenolic patterns in plants and associated litters and humus of a mountain forest ecosystem. Soil Biology \& Biochemistry 27, 157-165.

Gallet, C., Nilsson, M.C., Zackrisson, O., 1999. Phenolic metabolites of ecological significance in Empetrum hermaphroditum leaves and associated humus. Plant \& Soil 210, 1-9.

Gillet, S., Ponge, J.F., 2002. Humus forms and metal pollution in soil. European Journal of Soil Science 53, 529-540.

Gimingham, C.H., Chapman, S.B., Webb, N.R., 1979. European heathlands. In: Specht, R.L. (Ed.), Heathlands and Related Scrublands. Descriptive Studies. Elsevier, Amsterdam, pp. 365-413.

Graefe, U., 1990. Untersuchungen zum Einfluss von Kompensationskalkung und Bodenarbeitung auf die Zersetzerfauna in einem bodensauren Buchenwald- und Fichtenforst-Ökosystem. Forschung und Beratung, Series C 48, 232-241.

Green, R.N., Trowbridge, R.L., Klinka, K., 1993. Towards a taxonomic classification of humus forms. Forest Science Monographs 29, 1-49.

Grime, J.P., 1987. Dominant and subordinate components of plant communities: implications for succession, stability and diversity. In: Grayn, A.J., Crawley, M.J., Edwards, P.J. (Eds.), Colonization, Succession, and Stability. Blackwell, Oxford, pp. 413-428.

Grime, J.P., 1997. La biodiversité n'est pas une fin en soi, I'urgence est d'identifier les espèces irremplaçables. La Recherche 304, 40-41.

Grime, J.P., 1998. Benefits of plant diversity to ecosystems: immediate, filter and founder effects. The Journal of Ecology 86, 902-910.

Grime, J.P., Hodgson, J.G., 1987. Botanical contributions to contemporary ecological theory. The New Phytologist 106 Suppl., 283-295.

Grime, J.P., Mackey, J.M.L., Hillier, S.H., Read, D.J., 1987. Floristic diversity in a model system using experimental microcosms. Nature 328, 420-422.

Hansen, R.A., 2000. Effects of habitat complexity and composition on a diverse litter-microarthropod assemblage. Ecology 81, 1120-1132.

Haukka, J.K., 1987. Growth and survival of Eisenia fetida (Sav.) (Oligochaeta: Lumbricidae) in relation to temperature, moisture and presence of Enchytraeus albidus (Henle) (Enchytraeidae). Biology \& Fertility of Soils 3, 99-102. 
Hayes, M.H.B., 1983. Darwin's 'vegetable mould' and some modern concepts of humus structure and soil aggregation. In: Satchell, J.E. (Ed.), Earthworm Ecology. From Darwin to Vermiculture. Chapman \& Hall, London, pp. 19-33.

Heard, S.B., 1994. Processing chain ecology: resource condition and interspecific interactions. Journal of Animal Ecology 63, 451-464.

Heilman, P.E., 1966. Change in distribution and availability of nitrogen with forest succession on north slopes in Interior Alaska. Ecology 47, 825-831.

Hintikka, V., 1970. Studies on white-rot humus formed by higher fungi in forest soils. Communicationes Instituti Forestalis Fenniae 69.2, 1-68.

Hooper, D.U., Bignell, D.E., Brown, V.K., Brussaard, L., Dangerfield, J.M., Wall, D.H., Wardle, D.A., Coleman, D.C., Giller, K.E., Lavelle, P., Van der Putten, W.H., De Ruiter, P.C., Rusek, J., Silver, W.L., Tiedje, J.M., Wolters, V., 2000. Interactions between aboveground biodiversity in terrestrial ecosystems: patterns, mechanisms, and feedbacks. BioScience 50, 1049-1061.

Howard, P.J.A., Howard, D.M., 1990. Titratable acids and bases in tree and shrub leaf litter. Forestry 63, 177-196.

Huhta, V., Koskenniemi, A., 1975. Numbers, biomass and community respiration of soil invertebrates in spruce forests at two latitudes in Finland. Annales Zoologici Fennici 12, 164-182.

Hutchings, M.J., Wijesinghe, D.K., 1997. Patchy habitats, division of labour and growth dividends in clonal plants. Trends in Ecology \& Evolution 12, 390-394.

Hutchinson, G.E., 1959. Homage to Santa Rosalia, or why are there so many kinds of animals? The American Naturalist 93, 145-159.

Jarvis, P.G., 1964. Interference by Deschampsia flexuosa (L.) Trin. Oikos 15, 56-78.

Kaagman, M., Fanta, J., 1993. Cyclic succession in heathland under enhanced nitrogen deposition: a case study from the Netherlands. Scripta Geobotanica 21, 29-38.

Kevan, P.G., Chaloner, W.G., Savile, D.B.O., 1975. Interrelationships of early terrestrial arthropods and plants. Palaeontology 18, 391-417.

Kimmins, J.P., 1977. Evaluation of the consequences for future tree productivity of the loss of nutrients in whole-tree harvesting. Forest Ecology and Management 1, 169-183.

Klironomos, J.N., Hart, M.M., 2001. Animal nitrogen swap for plant carbon. Nature 410, 651-652.

Koerner, W., Dupuey, J.L., Dambrine, E., Benoît, M., 1997. Influence of past land use on the vegetation and soils of present day forest in the Vosges mountains, France. Journal of Ecology 85, 351-358.

Labandeira, C.C., Philips, T.L., Norton, R.A., 1997. Oribatid mites and the decomposition of plant tissues in palaeozoic coal-swamp forests. Palaios 12, 319-353.

Lafond, A., 1950. Oxidation-reduction potential as a characteristic of forest humus types. Soil Science Society of America Proceedings 14, 337-340.

Landeweert, R., Hoffland, E., Finlay, R.D., Kuyper, T.W., Van Breemen, N., 2001. Linking plants to rocks: ectomycorrhizal fungi mobilize nutrients from minerals. Trends in Ecology and Evolution $16,248-254$. 
Laskowski, R., Berg, B., 1993. Dynamics of some mineral nutrients and heavy metals in decomposing forest litter. Scandinavian Journal of Forest Research 8, 446-456.

Lavelle, P., 2000. Ecological challenges for soil science. Soil Science 165, 73-86.

Lavelle, P., Bignell, D., Lepage, M., Wolters, V., Roger, P., Ineson, P., Heal, O.W., Dhillion, S., 1997. Soil function in a changing world: the role of invertebrate ecosystem engineers. European Journal of Soil Biology 33, 159-193.

Lee, J.A., 1999. The calcicole-calcifuge problem revisited. Advances in Botanical Research 29, 1-30.

McCook, L.J., 1994. Understanding ecological community succession: causal models and theories, a review. Vegetatio 110, 115-147.

Majer, J.D., 1984. Short-term responses of soil and litter invertebrates to a cool autumn burn in jarrah (Eucalyptus marginata) forest in Western Australia. Pedobiologia 26, 229-247.

Marshall, K.C., 1975. Clay mineralogy in relation to survival of soil bacteria. Annual Review of Phytopathology 13, 357-373.

Marx, D.H., 1969. The influence of ectotrophic mycorrhizal fungi on the resistance of pine roots to pathogenic infections. I. Antagonism of mycorrhizal fungi to root pathogenic fungi and soil bacteria. Phytopathology 59, 153-163.

Menge, B.A., Sutherland, J.P., 1987. Community regulation: variation in disturbance, competition, and predation in relation to environmental stress and recruitment. The American Naturalist 130, 730-757.

Meyen, S.V., 1987. Fundamentals of Palaeobotany. Chapman and Hall, London.

Meyer, F.H., 1964. The role of the fungus Cenococcum graniforme (Sow.) Ferd. et Winge in the formation of mor. In: A. Jongerius (Ed.), Soil Micromorphology. Elsevier, Amsterdam, pp. 2331.

Miles, J., 1985. The pedogenic effects of different species and vegetation types and the implications of succession. Journal of Soil Science 36, 571-584.

Müller, P.E., 1889. Recherches sur les formes naturelles de l'humus et leur influence sur la végétation et le sol. Annales de la Science Agronomique Française et Étrangère 6, 85-423.

Muys, B., Lust, N., 1993. Ecological changes following afforestation with different tree species on a sandy loam in Flanders, Belgium. In: Watkins, C. (Ed.), Ecological effects of afforestation. CAB International, Wallingford, pp. 179-189.

Nagel-de-Boois H., Jansen, E., 1967. Hyphal activity in mull and mor of an oak forest. In: Graff, O., Satchell, J.E. (Eds.), Progress in Soil Biology. Vieweg, Braunschweig, pp. 27-36.

Näsholm, T., Ekblad, A., Nordin, A., Giesler, R., Högberg, M., Högberg, P., 1998. Boreal forest plants take up organic nitrogen. Nature 392, 914-916.

Nielsen, K.E., Dalgaard, K., Nørnberg, P., 1987. Effects on soils of an oak invasion of a Calluna heath, Denmark. I. Morphology and chemistry. Geoderma 41, 79-95.

Nihlgård, B., 1971. Pedological influence of spruce planted on former beech forest soils in Scania, South Sweden. Oikos 22, 302-314.

Nilsson, S.I., Miller, H.G., Miller, J.D., 1982. Forest growth as a possible cause of soil and water acidification: an examination of the concepts. Oikos 39, 40-49. 
Northup, R.R., Dahlgren, R.A., McColl, J.G., 1998. Polyphenols as regulators of plant-litter-soil interactions in northern California's pygmy forest: a positive feedback? Biogeochemistry 42 , 189-220.

Northup, R.R., Yu, Z., Dahlgren, R.A., Vogt, K.A., 1995. Polyphenol control of nitrogen release from pine litter. Nature 377, 227-228.

Odum, E.P., 1969. The strategy of ecosystem development. Science 164, 262-270.

Oldeman, R.A.A., 1990. Forests: Elements of Silvology. Springer, Berlin.

Page, G., 1968. Some effects of conifer crops on soil properties. Commonwealth Forestry Review 47, $52-62$.

Page, G., 1974. Effects of forest cover on the properties of some Newfoundland forest soils. Canadian Forestry Service, Ottawa.

Perry, D.A., Amaranthus, M.P., Borchers, J.G., Borchers, S.L., Brainerd, R.E., 1989. Bootstrapping in ecosystems. BioScience 39, 230-237.

Petersen, H., Luxton, M., 1982. A comparative analysis of soil fauna populations and their role in decomposition processes. Oikos 39, 287-388.

Piearce, T.G., 1972. The calcium relations of selected Lumbricidae. The Journal of Animal Ecology 41, 167-188.

Ponge, J.F., 1990. Ecological study of a forest humus by observing a small volume. I. Penetration of pine litter by mycorrhizal fungi. European Journal of Forest Pathology 20, 290-303.

Ponge, J.F., 1993. Biocenoses of Collembola in atlantic temperate grass-woodland ecosystems. Pedobiologia 37, 223-244.

Ponge, J.F., 1999. Interaction between soil fauna and their environment. In: Rastin, N., Bauhus, J. (Eds.), Going Underground. Ecological Studies in Forest Soils. Research Signpost, Trivandrum, pp. 45-76.

Ponge, J.F., 2000. Acidophilic Collembola: living fossils? Contributions from the Biological Laboratory, Kyoto University 29, 65-74.

Ponge, J.F., André, J., Zackrisson, O., Bernier, N., Nilsson, M.C., Gallet, C., 1998. The forest regeneration puzzle. BioScience 48, 523-530.

Ponge, J.F., Arpin, P., Sondag, F., Delecour, F., 1997. Soil fauna and site assessment in beech stands of the Belgian Ardennes. Canadian Journal of Forest Research 27, 2053-2064.

Ponge, J.F., Charnet, F., Allouard, J.M., 2000. Comment distinguer dysmoder et mor? L'exemple de la forêt domaniale de Perche-Trappe (Orne). Revue Forestière Française 52, 23-37.

Ponge, J.F., Delhaye, L., 1995. The heterogeneity of humus profiles and earthworm communities in a virgin beech forest. Biology \& Fertility of Soils 20, 24-32.

Ponge, J.F., Patzel, N., Delhaye, L., Devigne, E., Levieux, C., Beros, P., Wittebroodt, R., 1999. Interactions between earthworms, litter and trees in an old-growth beech forest. Biology \& Fertility of Soils $29,360-370$.

Ponsard, S., Arditi, R., Jost, C., 2000. Assessing top-down and bottom-up control in a litter-based soil macroinvertebrate food chain. Oikos 89, 524-540. 
Price, P.W., 1988. An overview of organismal interactions in ecosystems in evolutionary and ecological time. Agriculture, Ecosystems and Environment 24, 369-377.

Read, D.J., 1991. Mycorrhizas in ecosystems. Experientia 47, 376-391.

Read, D.J., Kerley, S., 1995. The status and function of ericoid mycorrhizal systems. In: Read, D.J., Kerley, S. (Eds.), Mycorrhiza. Structure, Function, Molecular Biology and Biotechnology. Springer, Berlin, pp. 501-520.

Retallack, G.J., 1985. Fossil soils as grounds for interpreting the advent of large plants and animals on land. Philosophical Transactions from the Royal Society of London, Series B, Biological Sciences 309, 105-142.

Retallack, G.J., 1986. The fossil record of soils. In: Wright, V.P. (Ed.), Paleosols: their Recognition and Interpretation. Blackwell, Oxford, pp. 1-57.

Roem, W.J., Berendse, F., 2000. Soil acidity and nutrient supply ratio as possible factors determining changes in plant species diversity in grassland and heathland communities. Biological Conservation 92, 151-161.

Römbke, J., 1987. Population dynamics of Oligochaeta of a beech forest in the Northern Black Forest (FRG). In: Striganova, B.R. (Ed.), Soil Fauna and Soil Fertility. Nauka, Moscow, pp. 446-448.

Römbke, J., 1989. Lebensraum Buchenwaldboden. IX. Die Enchytraeen und Regenwürmer. Verhandlungen der Gesellschaft für Ökologie 17, 97-101.

Rusek, J., 1978. Pedozootische Sukzessionen während der Entwicklung von Ökosystemen. Pedobiologia 18, 426-433.

Schaefer, M., 1990. The soil fauna of a beech forest on limestone: trophic structure and energy budget. Oecologia 82, 128-136.

Schaefer, M., 1991. Fauna of the European temperate deciduous forest. In: Röhrig, E., Ulrich, B. (Eds.), Ecosystems of the World. VII. Temperate Deciduous Forests. Elsevier, Amsterdam, pp. 503-525.

Schaefer, M., Schauermann, J., 1990. The soil fauna of beech forests: comparison between a mull and a moder soil. Pedobiologia 34, 299-314.

Scheu, S., Theenhaus, A., Jones, T.H., 1999. Links between the detritivore and the herbivore system: effects of earthworms and Collembola on plant growth and aphid development. Oecologia $119,541-551$.

Schrader, S., 1994. Influence of earthworms on the $\mathrm{pH}$ conditions of their environment by cutaneous mucus secretion. Zoologischer Anzeiger 5/6, 211-219.

Schwartz, M.W., Brigham, C.A., Hoeksema, J.D., Lyons, K.G., Mills, M.H., Van Mantgem, P.J., 2000. Linking biodiversity to ecosystem function: implications for conservation ecology. Oecologia 122, 297-305.

Sexstone, A.J., Mains, C.N., 1990. Production of methane and ethylene in organic horizons of spruce forest soils. Soil Biology \& Biochemistry 22, 135-139.

Sokal, R.R., Rohlf, F.J., 1995. Biometry. The principles and practice of statistics in biological research, $3^{\text {rd }}$ ed. Freeman, New York. 
Sprugel, D.G., 1991. Disturbance, equilibrium, and environmental variability: what is 'natural' vegetation in a changing environment? Biological Conservation 58, 1-18.

Staaf, H., 1987. Foliage turnover and earthworm populations in three beech forests of contrasting soil and vegetation types. Oecologia 72, 58-64.

Standen, V., 1984. Production and diversity of enchytraeids, earthworms and plants in fertilized hay meadow plots. Journal of Applied Ecology 21, 293-312.

Stevenson, F.J., 1994. Humus Chemistry. Genesis, Composition, Reactions, $2^{\text {nd }}$ ed. Wiley, New York.

Takao, S., 1965. Organic acid production by basidiomycetes. I. Screening of acid-producing strains. Applied Microbiology 13, 732-737.

Teuben, A., Verhoef, H.A., 1992. Direct contribution by soil arthropods to nutrient availability through body and faecal nutrient content. Biology \& Fertility of Soils 14, 71-75.

Tilman, D., 1996. Biodiversity: population versus ecosystem stability. Ecology 77, 350-363.

Tilman, D., Downing, J.A., 1994. Biodiversity and stability in grasslands. Nature 367, 363-365.

Tilman, D., Knops, J., Wedin, D., Reich, P., Ritchie, M., Siemann, E., 1997. The influence of functional diversity and composition on ecosystem processes. Science 277, 1300-1302.

Topoliantz, S., Ponge, J.F., Viaux, P., 2000. Earthworm and enchytraeid activity under different arable farming systems, as exemplified by biogenic structures. Plant \& Soil 225, 39-51.

Ulrich, B., 1987. Stability, elasticity, and resilience of terrestrial ecosystems with respect to matter balance. Ecological studies 61, 11-49.

Van Vuuren, M.M.I., Aerts, R., Berendse, F., De Visser, W., 1992. Nitrogen mineralization in heathland ecosystem dominated by different plant species. Biogeochemistry 16, 151-166.

Vedder, B., Kampichler, C., Bachmann, G., Bruckner, A., Kandeler, E., 1996. Impact of faunal complexity on microbial biomass and $\mathrm{N}$ turnover in field mesocosms from a spruce forest soil. Biology \& Fertility of Soils 22, 22-30.

Verdier, B., 1975. Étude de l'atmosphère du sol. Éléments de comparaison et signification écologique de l'atmosphère d'un sol brun calcaire et d'un sol lessivé podzolique. Revue d'Écologie et de Biologie du Sol 12, 591-626.

Vitousek, P., 1982. Nutrient cycling and nutrient use efficiency. The American Naturalist 119, 553-572.

Vitousek, P.M., Reiners, W.A., 1975. Ecosystem succession and nutrient retention: a hypothesis. BioScience 25, 376-381.

Wall, D.H., Moore, J.C., 1999. Interactions underground. Soil biodiversity, mutualism, and ecosystem processes. BioScience 49, 109-117.

Wardle, D.A., Nilsson, M.C., Gallet, C., Zackrisson, O., 1998. An ecosystem-level perspective of allelopathy. Biological Reviews of the Cambridge Philosophical Society 73, 305-319.

Wardle, D.A., Zackrisson, O., Hörnberg, G., Gallet, C., 1997. The influence of island area on ecosystem properties. Science 277, 1296-1299.

Wauthy, G., 1982. Synecology of forest soil oribatid mites of Belgium (Acari, Oribatida). Acta Oecologica, Oecologia Generalis 3, 469-494. 
Webb, D.P., 1977. Regulation of deciduous forest litter decomposition by soil arthropod feces. In: Mattson, W.J. (Ed.), The Role of Arthropods in Forest Ecosystems. Springer, New York, pp. 57-69.

White, C.S., 1994. Monoterpenes: their effects on ecosystem nutrient cycling. Journal of Chemical Ecology 20, 1381-1406.

Wolters, V., 1988. Effects of Mesenchytraeus glandulosus (Oligochaeta, Enchytraeidae) on decomposition processes. Pedobiologia 32, 387-398.

Wolters, V., 1998. Functional aspects of animal diversity in soil. Introduction and overview. Applied Soil Ecology 10, 185-190.

Wolters, V., 1999. Allium ursinum litter triggering decomposition on a beech forest floor. The effect of earthworms. Pedobiologia 43, 528-536.

Zackrisson, O., Nilsson, M.C., Wardle, D.A., 1996. Key ecological function of charcoal from wildfire in the boreal forest. Oikos 77, 10-19. 


\section{Figure captions}

Fig. 1. The decrease in soil zoological richness (number of higher invertebrate taxa belonging to macro- and mesofauna) observed along an altitudinal gradient in 13 beech forest stands from the Belgian Ardennes. Black circles $=$ moder. White circles $=$ mull. See Ponge et al. (1997) for soil and litter chemical properties associated with altitude

Fig. 2. Changes in earthworm densities along a time sequence of spruce in a late-successional ecosystem at $1750 \mathrm{~m}$ altitude (Savoy, France). Eight even-aged clumps of trees (eco-units) have been selected in order to represent the age variability found within a 0.5 ha surface showing constant soil and aspect conditions. Data from Bernier and Ponge (1994)

Fig. 3. Densities of enchytraeid and lumbricid worms compiled according to Huhta and Koskenniemi (1975), Standen (1984), Römbke (1987, 1989), Graefe (1990), Schaefer (1991) and Ponge et al. (1997). Data were adjusted to a second-order hyperbolic equation after log $(x+1)$ transformation of earthworm densities followed by correlation analysis with enchytraeid densities (Sokal and Rohlf, 1995) 
Table 1. Main biological features of the three main humus forms at the ecosystem level

\begin{tabular}{|c|c|c|c|}
\hline & MULL & MODER & MOR \\
\hline Ecosystems & $\begin{array}{l}\text { Grasslands, deciduous } \\
\text { woodlands with rich herb } \\
\text { layer, Mediterranean } \\
\text { scrublands }\end{array}$ & $\begin{array}{l}\text { Deciduous and coniferous } \\
\text { woodlands with poor herb layer }\end{array}$ & $\begin{array}{l}\text { Heathlands, coniferous } \\
\text { woodlands, sphagnum bogs, } \\
\text { alpine meadows }\end{array}$ \\
\hline Biodiversity & High & Medium & Low \\
\hline Productivity & High & Medium & Low \\
\hline Litter horizons & OL, OF & $\mathrm{OL}, \mathrm{OF}, \mathrm{OH}$ & OL, OM \\
\hline Soil type & Brown soils & Grey-brown podzolic soils & Podzols \\
\hline Phenolic content of litter & Poor & Medium & High \\
\hline Humification & Rapid & Slow & Very slow \\
\hline Humified organic matter & $\begin{array}{l}\text { Organo-mineral aggregates } \\
\text { with clay-humus complexes }\end{array}$ & Holorganic faecal pellets & Slow oxidation of plant debris \\
\hline Exchange sites & Mineral & Organic (rich) & Organic (poor) \\
\hline Mineral weathering & High & Medium & Poor \\
\hline Mineral buffer type & Carbonate range & Silicate range & Iron/aluminum range \\
\hline Impact of fire & $\begin{array}{l}\text { Low (except in Mediterranean } \\
\text { ecosystems) }\end{array}$ & Medium & High \\
\hline Regeneration of trees & Easy (permanent) & Poor (cyclic processes) & None (fire needed) \\
\hline Dominant mycorrhizal types & VA-mycorrhizae & Ectomycorrhizae & $\begin{array}{l}\text { Ericoid and arbutoid } \\
\text { mycorrhizae }\end{array}$ \\
\hline Mycorrhizal partners & Zygomycetes & Basidiomycetes & Ascomycetes \\
\hline Nitrogen forms & Protein, ammonium, nitrate & Protein, ammonium & Protein \\
\hline Nutrient availability to plants & $\begin{array}{l}\text { Direct (through absorbing } \\
\text { hairs) }\end{array}$ & $\begin{array}{l}\text { Indirect (through extramatrical } \\
\text { mycelium) }\end{array}$ & Poor \\
\hline Nutrient use efficiency & Low & Medium & High \\
\hline Fauna & $\begin{array}{l}\text { Megafauna, macrofauna, } \\
\text { mesofauna, microfauna }\end{array}$ & $\begin{array}{l}\text { Macrofauna (poor), mesofauna } \\
\text { (rich), microfauna }\end{array}$ & $\begin{array}{l}\text { Mesofauna (poor), microfauna } \\
\text { (poor) }\end{array}$ \\
\hline Faunal group dominant in biomass & Earthworms & Enchytraeids & None \\
\hline Microbial group dominant in biomass & Bacteria & Fungi & None \\
\hline Affinities with polluted condition & Low & Medium & High \\
\hline
\end{tabular}




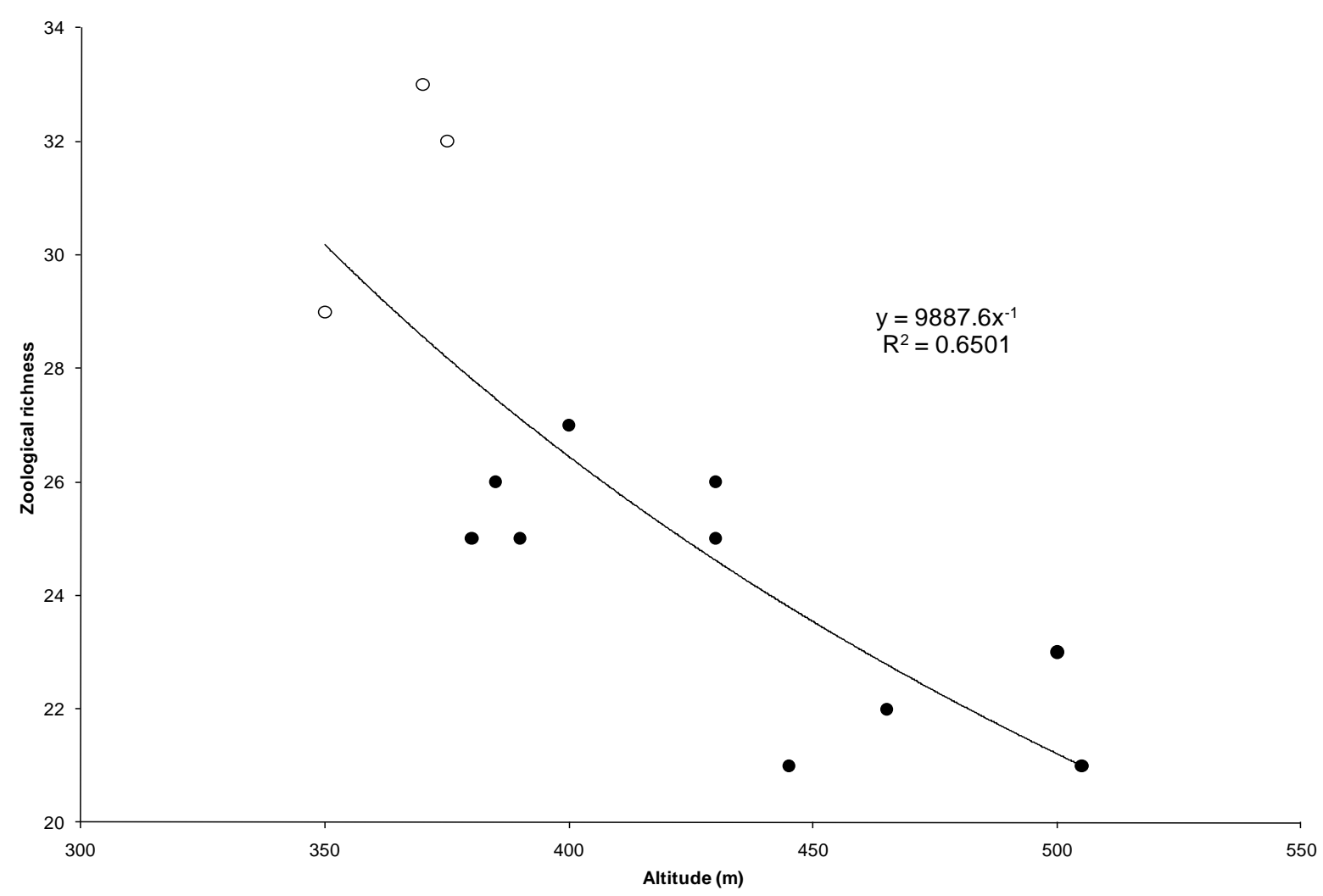

Fig. 1 


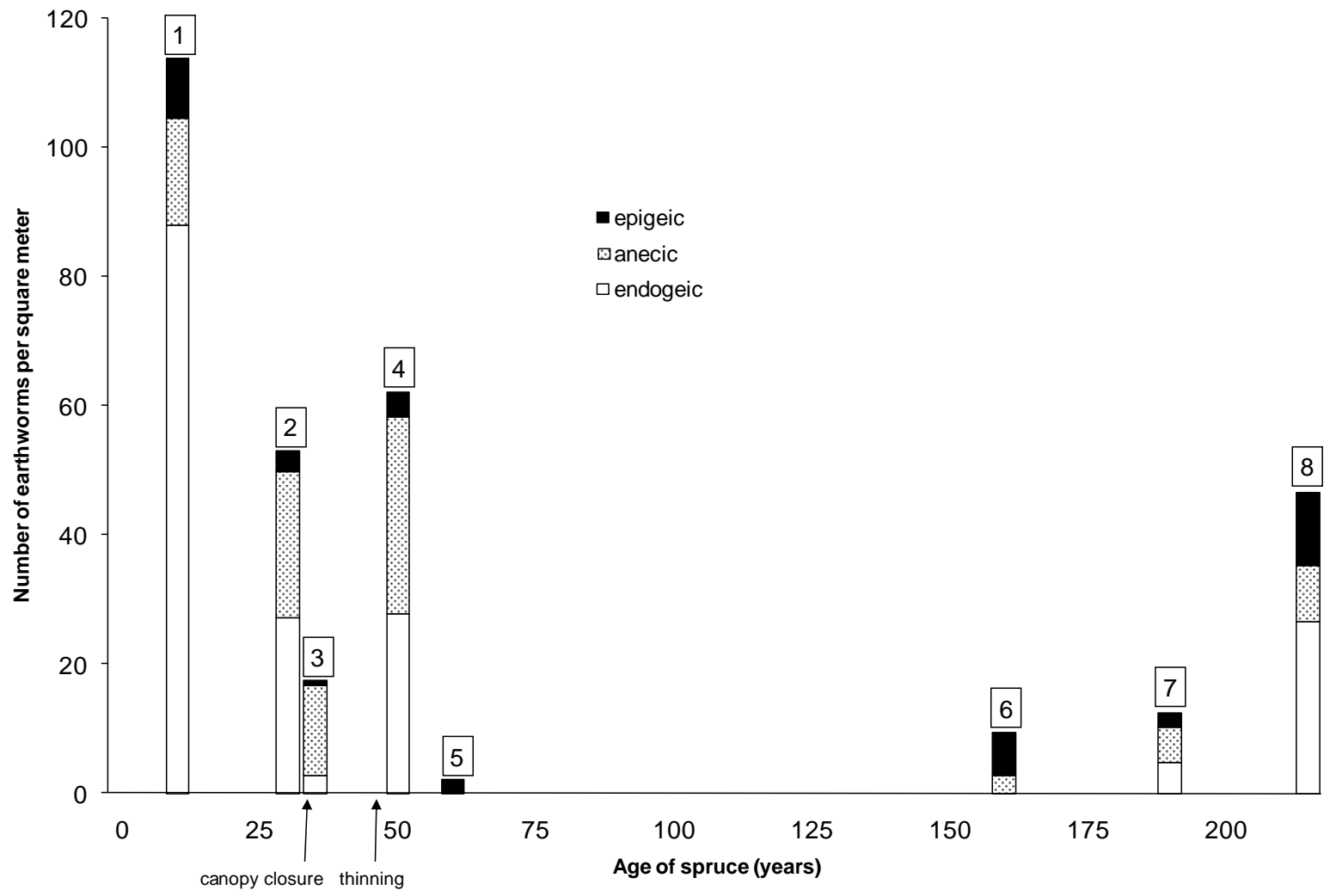

Fig. 2 
24

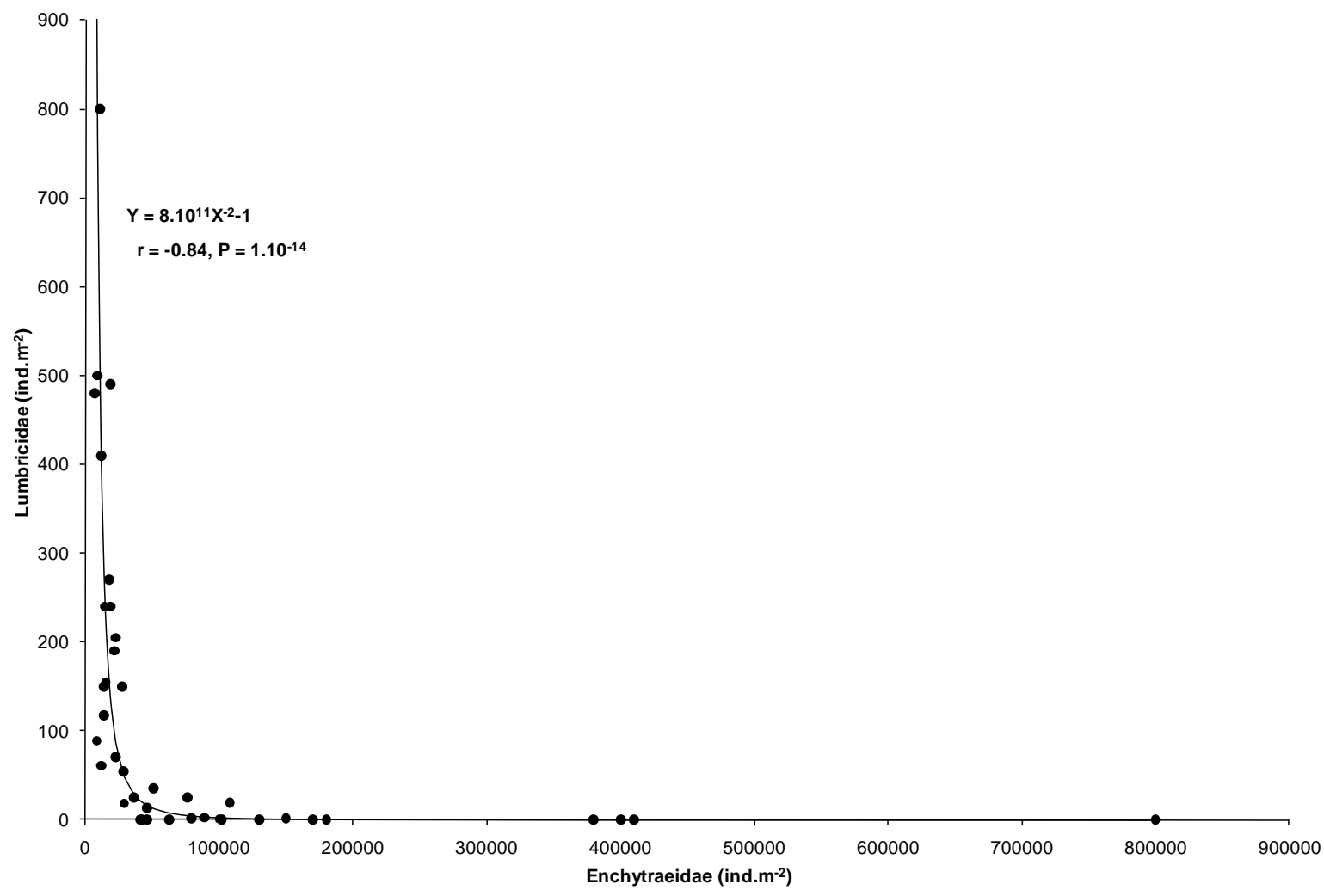

Fig. 3 